\title{
$\mathrm{HaCaT}$ 세포에서 Lactobacillus 혼합배양액 추출물이 아토피관련 케모카인 발현에 미치는 효과
}

\author{
홍수정 $^{1} \cdot$ 이원재 $^{1} \cdot$ 조을화 $^{2} \cdot$ 안성훈 $^{2}$ \\ ${ }^{1}$ 가천대학교 경영대학원 의료경영학교실, ${ }^{2}$ 원광대학교 한의과대학 경혈학교실
}

\section{The Effect of Lactobacillus Mixture Culture Fluid Extracts on Atopic Dermatitis Chemokine Expression of in HaCaT Cells}

\author{
Soo-Jeong Hong ${ }^{1}$, Won-Jae Lee ${ }^{1}$, Eul-Hwa Jo ${ }^{2}$, Seong-Hun Ahn ${ }^{2}$ \\ ${ }^{1}$ Department of Health Care Management Administration, Graduate School of Business Administration, Gachon University, \\ ${ }^{2}$ Department of Meridians and Acupoints, College of Korean Medicine, Wonkwang University
}

Objectives : Recently the case of lactobacillus mixture culture fluid appliment was reported. In this study, anti-inflamation effects and anti-allergy effects were studied by stimulus of lactobacillus mixture culture fluid extracts in HaCaT cells. Methods : The atopic dermatitis were induced by TNF- $\alpha$ and interferon- $\gamma$ in HaCaT cells. TARC/CCL17, MDC/CCL22, RANTES/CCL5 and ROS production were investigated to explain anti-inflamation and allergy effects of lactobacillus mixture culture fluid with cell-enzyme-linked Immunosorbent assay in $450 \mathrm{~nm}, 485 \mathrm{~nm}, 535 \mathrm{~nm}$ with spectro-fluorometer. Results : The extracts of lactobacillus mixture culture fluid were decreased TARC/CCL17, MDC/CCL22, RANTES/CCL5 expressions and ROS production with a concentration dependent manner. Conclusions : The effects mechanism of Lactobacillus mixed culture fluid for atopic dermatitis symptoms were considered to be explain anti-inflamation and allergy effects via control of cytokine, chemokine and ROS production, and the fluid could be applied in skin cells directly. But classified AD symptom degrees reported in clinical case before as Reaction Period, Reduction Period, Effect Period, Reproduction Period and Rebound Period could not be explained. Further study will be expected.

Key words : atopic dermatitis, lactobacillus mixted culture fluid, HaCaT cell, TARC/CCL17, MDC/CCL22, RANTES/CCL5

\section{서 론}

아토피피부염(Atopic dermatitis 또는 atopic eczema)은 주로 유아와 소아기에 발병하는 만성적으로 재발하는 알러지성 피부 염 증질환으로 심한 가려움증과 함께 홍반, 부종, 삼출, 피부건조, 가피, 인설 등의 1 차적 증상 ${ }^{1}$ 과 수면장애, 집중력 저하, 정서불안 등의 2차적 증상이이 나타난다고 보고되어 있다. 아토피피부염의 원인은
현재 정확한 원인이 밝혀지지는 않아 유전적 요인, 곰팡이 등과 같 은 환경적 요인 ${ }^{3)}$, 영양결핍 4,5$)$, 면역조절 불균형,(7), 피부장벽의 손 상 ${ }^{8)}$, 위장기능의 장애》) 등 다양한 원인에 의해서 발병할 것이라고 추정하고 있으며 치료방법으로는 스테로이드, 항히스타민제, 인테 페론감마, 사이모펜틴, 칼시뉴린억제제, 항생제, 항진균제, 해양미 네랄 피부도포 등의 방법이 있었으나 장시간 사용했을 경우 나타나 는 부작용 등의 문제점이 대두되어 보다 안전한 한약제제, 천연물

Received March 28, 2017, Revised May 27, 2017, Accepted May 31, 2017

Corresponding author: Seong-Hun Ahn

Department of Meridians \& Acupoints, College of Korean Medicine, Wonkwang University, 344-2, Shinyong-dong, Iksan 54538, Korea

Tel: +82-63-850-6983, Fax: +82-63-857-6458, E-mail: drpoint@wku.ac.kr

This work (Grants No. c0395584) were supported by Business for Cooperative R\&D between Industry, Academy and Research Institute funded Korea Small and Medium Business Administration in 2016.

(C) This is an open access article distributed under the terms of the Creative Commons Attribution Non-Commercial License (http://creativecommons.org/licenses/ by-nc/4.0) which permits unrestricted non-commercial use, distribution, and reproduction in any medium, provided the original work is properly cited. 
제재를 소재로 하는 다양한 치료방법 및 제제 등이 연구되고 있다.

한편 최근에 아토피피부염과 미생물과 관련되어 최근에 연구되고 있는 아토피피부염과 연관이 있는 유산균의 종류는 Lactobacillus rhmmosus GG, Lactobacillus bifermentans, Lactobasillus plantarum 등 ${ }^{10-15)}$ 으로 아토피피부염에 유효하다는 긍정적인 보고 ${ }^{10-15)}$ 와 유효하지 않다는 부정적인 보고 ${ }^{16-18)}$ 가 혼재되어 있는 실정이다. 이와 관련하여 본 연구실에서는 lactobacillus 혼합배양액에 황토 를 가미하여 아토피피부염 환부에 직접 도포한 최근의 시례 발표를 통하여 기존의 경구투여 방식과는 다른 피부도포 방식으로 아토피 피부염에 유효한 결과를 발표19)하였다.

본 연구에서는 Lactobacillus 혼합배양액의 임상사례에 근거하 여 항알러지 효과를 연구하고자 표피의 대부분을 차지하는 각질 형성세포로서, 다양한 염증성 사이토카인(cytokine)과 케모카인 (chemokine)을 생성하여 피부의 면역반응실험에 주로 사용되고 있는 $\mathrm{HaCaT}$ 세포를 이용하여 TNF- $\alpha$ 와 interferon- $\gamma$ (IFN- $\gamma$ ) 로 알러지반응을 유도하였고, Lactobacillus 혼합배양액을 동결건 조하여 후처리한 후, 알러지 반응에 있어 중요한 표적물질로 알려 진 Thymus \& activation-regulated chemokine(TARC/CCL17), macrophage-derived chemokine(MDC/CCL22) 및 regulated on activation normal T-cell expression and secreted (RANTES/ CCL5)와 같은 케모카인의 생성량을 확인하여 유의한 결과가 나왔 기에 보고하는 바이다.

\section{재료 및 방법}

\section{1. 시약}

세포 배양액인 Dulbecco's modified Eagle's medium(DMEM), fetal bovine serum(FBS), penicillin-streptomycin, phosphate-buffered saline(PBS)은 Gibco BRL사(NY, USA), TNF- $\alpha$, IFN- $\gamma$ 은 R\&D systems(Minneapolis, MN, USA) 제품을 구입하 였다. 실험에 사용된 모든 시약은 분석용 등급이상으로 사용하였다.

\section{2. 시료의 제조}

혼합배양액은 Lactobasillus brevis 균주와 Pediococcus acidilactici 균주(10 15 g/L, 균주의 순도 99.9)를 인삼, 황기, 감초, 견우자, 녹차, 노회를 혼합 절편 $(1.5 \sim 2.0 \mathrm{~mm})$ 하여 $15 \sim 20^{\circ} \mathrm{C}$ 상 온에서 1년간 배양(밀폐, 차광, 항온항습기 조건)시킨 후 조성되는 배양액을 여과지를 이용하여 여과한 다음, 여과액을 evaporator (EYELA, Japan)을 이용하여 감압 농축하고 농축액을 동결 건조
(Martin Crist, Alpha 1 4 LSCpuls, German)하여 추출물(이하 배양추출물)을 만들고 실험 시까지 냉동보관 하였다. 실험 시에는 배양추출물을 pure distilled water를 이용하여 배지에 녹인 후, pore size $0.45 \mu \mathrm{m}$ 의 여과지를 통과시킨 후 사용하였다. 한약제 추출물 성분비는 하기 Table 1과 같다(Table 1).

\section{3. 세포 배양}

$\mathrm{HaCaT}($ human keratinocyte cell) 세포주는 원광대학교 문연자 교수(Iksan, Korea)로부터 분양 받아 사용하였다. 세포 배양을 위 해 $\mathrm{HaCaT}$ 세포는 $10 \% \mathrm{FBS}$ 가 포함된 DMEM 배지에 $1 \%$ penicillin-streptomycin을 첨가하여 $37^{\circ} \mathrm{C}, 5 \% \mathrm{CO}_{2}$ 조건에서 배양하였 다.

\section{4. 세포독성 평가}

세포 독성을 평가하기 위하여 $50 \mathrm{mg}$ 의 MTT(3-(4,5-dimethylthiazol-2-yl-2,5-diphenyl tetrazolium bromide) 시약을 phosphate buffered saline(PBS) $100 \mathrm{~m}$ 에 녹여 $0.2 \mu \mathrm{m}$ syringe filter로 여과한 후 사용하였다. 배양 추출물을 농도별로 $\mathrm{HaCaT}$ 세 포에 처리하였고, 24 시간 동안 배양하였다. 그 후 상층의 배지에 MTT 용액 $20 \mu 1$ 첨가하고 알루미늄 호일로 plate를 가린 후 $37^{\circ} \mathrm{C}$ 에서 4시간 반응시켰다. 상층액을 제거한 후 $\mathrm{DMSO}$ 를 $200 \mu 1$ 넣어 실온에서 20분간 흔들어 혼합시킨 후 ELISA reader로 $570 \mathrm{~nm}$ 에 서 시간에 따른 오차 없이 동시에 흡광도를 측정하였다.

\section{ROS 생성 측정}

세포 내 ROS의 생성 정도를 측정하기 위하여 2',7'-dichlorofluorescein diacetate(CM- $\mathrm{H}_{2} \mathrm{DCFDA}$, Invitrogen) 형광염료를 이 용하였다. 근접 빛이 차단된 96-well dish에 $1 \times 10^{4}$ cells을 각각 seeding 한 후, 세포가 약 $70 \%$ 가량 자랐을 때 $0.5 \% \mathrm{FBS}$ DMEM 배지로 배양해 주었다. 각 조건별로 24시간 동안 배양한 후 $1 \mathrm{X} \mathrm{PBS}$ 로 두 번 세척해 준 후 새로운 $1 \mathrm{X}$ PBS와 함께 final 농도가 $10 \mu \mathrm{M}$ 이 되도록 $\mathrm{CM}-\mathrm{H}_{2} \mathrm{DCFDA}$ 를 첨가하여 30 분간 반응시켰다. 반응 종

Table 1. Compositions of Herbal Mixture Extracts

\begin{tabular}{lc}
\hline \multicolumn{1}{c}{ Ingredient } & Contents(\%) \\
\hline 인삼(Panax Ginseng C.A.Meyer) & 13 \\
황기(Astragalus membranaceus Bunge var.) & 13 \\
감초(Glycyrrhiza uralensis Fischer) & 18 \\
견우자(Pharbitidis nil Choisy) & 13 \\
녹차(Camellia sinensis C.V. Linne.) & 13 \\
노회(Aloe ferox Miller) & 30 \\
\hline
\end{tabular}


료 후, spectrofluorometer(Infinite F200 pro, TECAN)를 이용하 여 $485 \mathrm{~nm}$ 와 $535 \mathrm{~nm}$ 에서 형광 $\mathrm{DCF}$ 를 측정하여 대조군에 대한 상대적인 수치로 나타내었다.

\section{Cell Enzyme-Linked Immunosorbent assay}

$\mathrm{HaCaT}$ 세포에서 케모카인의 측정은 cell ELISA를 이용하였다. 96 well plate에 $\mathrm{HaCaT}$ 세포를 $1 \times 10^{4}$ cells/plate 분주하여 배양 한 후 충분히 자란 상태가 되었을 때 $0.2 \% \mathrm{FBS}$ 로 배지를 바꿔주었 다. 배양 추출물을 농도별로 첨가하여 1 시간 배양하였고, TNF- $\alpha$ $10 \mathrm{ng} / \mathrm{m}$ 과 IFN- $\gamma 10 \mathrm{ng} / \mathrm{ml}$ 을 투여한 후 24 시간 더 배양하였다. 배양이 끝난 후 상층액을 버리고 PBS로 3회 세척한 후 $1 \%$ formaldehyde로 30분간 실온에서 고정하였다. PBS-Tween 20으로 3회 세척 후 $1 \%$ Bovine serum albumin(BSA)/PBS를 각 well에 200 $\mu 1$ 씩 넣고 $37^{\circ} \mathrm{C}$ 에서 1 시간 반응시켰다. 상층액을 버린 후 1,000 배 희석된 anti-human TARC, IF-8, MDC, RANTES 단클론 항체를 각 well 당 $100 \mu$ 씩 넣고, $4^{\circ} \mathrm{C}$ 에서 하룻밤 반응시킨 후 PBS-Tween 20 으로 3번 세척하였다. 2,000배로 희석된 peroxidase conjugated goat anti-mouse IgG를 2차 항체로 각 well당 $100 \mu$ 씩 첨가하 여 $37^{\circ} \mathrm{C}$ 에서 1 시간 반응시켰다. 배양 후 PBS-Tween20로 3회 세 척하였다. $100 \mathrm{ml} 0.05 \mathrm{M}$ citrate-phosphate buffer에 $40 \mathrm{mg}$ O-phenylenediamine(Sigma, USA)과 $10 \mu 1 \mathrm{H}_{2} \mathrm{O}_{2}$ 가 포함된 peroxidase substrate 발색용액을 각 well당 $100 \mu$ 씩 넣어 실온 에서 30분간 발색시킨 후 $5 \mathrm{~N} \mathrm{H}_{2} \mathrm{SO}_{4}$ 용액을 동량 넣어 반응을 정지시켰다. 이를 컴퓨터가 부착된 microplate reader를 사용하여

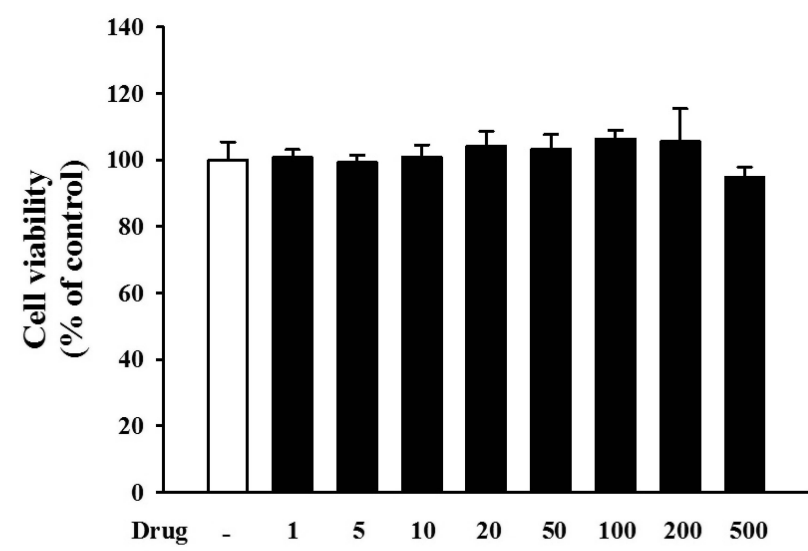

Fig. 1. Effect of Lactobacillus mixture culture fluid extracts on the viability of $\mathrm{HaCaT}$ cell.

$\mathrm{HaCaT}$ cell viability was assessed by MTT after $24 \mathrm{~h}$ incubation of Lactobacillus mixture culture fluid extracts. Data are expressed as percent cell viability relative to Lactobacillus mixture culture fluid extracts and treatment with $0.1 \%$ dimetyl sulfoxide(control) (viability $=100 \%)$ Values are mean \pm S.E. $(n=3$, individual experiments).
$450 \mathrm{~nm}$ 에서 흡광도를 측정하였다.

\section{7. 통계분석}

실험군 간의 유의성은 Systat사의 SigmaPlot 10.0을 이용하여 실험 결과를 $\mathrm{ANOVA}$ 분석법을 통하여 $p$ 값이 0.05 이하인 경우 유의한 차이로 판정하였고, 실험 치의 표현은 mean \pm S.E.로 하였다.

\section{결과 및 고찰}

\section{1. 세포생존률에 미치는 효과}

인간의 피부 각질형성세포주에서 배양추출물이 미치는 세포독 성 효과를 알아보기 위하여 1 500 $\mu \mathrm{g} / \mathrm{ml}$ 농도 범위에서 MTT assay를 수행하였다. 배양추출물을 처리한 결과 $200 \mu \mathrm{g} / \mathrm{ml}$ 농도 까지 MTT 흡광도에는 유의한 변화는 보이지 않았고 $500 \mu \mathrm{g} / \mathrm{ml}$ 에서 세포 생존율이 감소하는 경향은 보였으나 유의성은 보이지 않았다. 그러므로 본 실험에서는 세포 생존율에 영향을 주지 않는 최소 농도를 사용하였다(Fig. 1).

\section{2. 항산화 효과 분석}

세포에 산화스트레스가 가해져서 케모카인 발현의 변화를 통해 다양한 반응을 나타내기 위해서는 세포내 신호전달 체계가 관여하

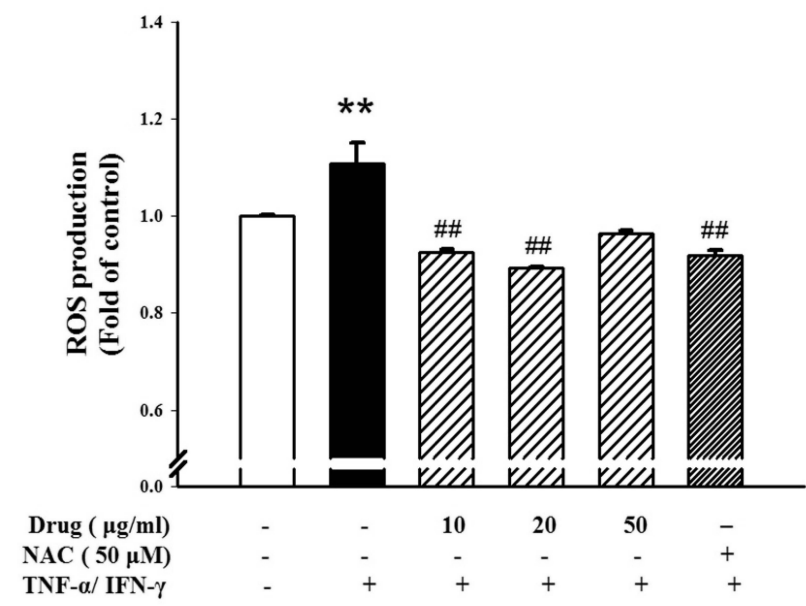

Fig. 2. Effects of Lactobacillus mixture culture fluid extracts on TNF- $\alpha$ and IFN $-\gamma$-induced ROS production.

$\mathrm{HaCaT}$ cells were pretreated with Lactobacillus mixture culture fluid extracts for $1 \mathrm{~h}$ and incubation with TNF- $\alpha$ and IFN $-\gamma$ for $24 \mathrm{hr}$. This was followed by stimulation with $5 \mu \mathrm{M}$ DCFDA. The fluorescence intensity of cells was measured using a fluorescence microplate. ${ }^{* *} p<0.01$,vs. control; ${ }^{\#} p<0.05,{ }^{\# \#} p<0.01$, vs. TNF- $\alpha$ treated alone. Values are mean $\pm S$.E.( $n=3$, individual experiments). 
게 된다. 신호전달체계는 핵 내에서 케모카인 발현의 조절에 핵심 적인 역할을 하게 되며 그런 의미에서 산화성 스트레스 ROS는 second messenger라고 할 수 있다. 그러므로 배양추출물이 TNF$\alpha$ 과 IFN- $\gamma$ 에 유도된 세포내 $\mathrm{ROS}$ 를 감소시킬 수 있는지를 $\mathrm{CM}-\mathrm{H}_{2} \mathrm{DCFDA}$ 을 이용하여 측정하였다. 세포내 활성산소의 생성이 증가하였으나 배양추출물을 전 처리하였을 때는 TNF- $\alpha$ 과 IFN$\gamma$ 로 인한 활성산소 생성이 유의하게 억제되었다(Fig. 2). 이것은 배양추출물이 높은 항산화 활성이 있다고 할 수 있다.
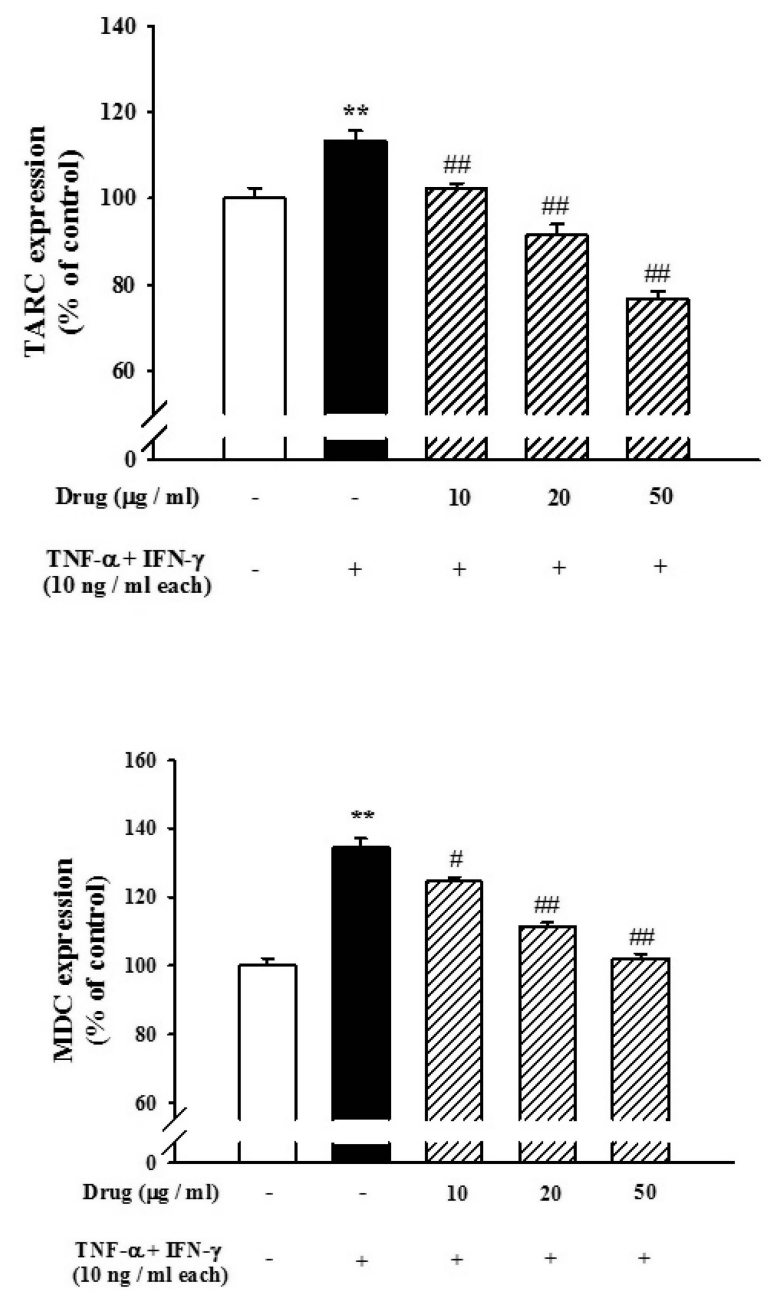

Fig. 3. Effects of Lactobacillus mixture culture fluid extracts on the TARC/CCL17 and MDC/CCL22 expression.

$\mathrm{HaCaT}$ cells were pretreated with Lactobacillus mixture culture fluid extracts for $1 \mathrm{~h}$ and then stimulated with TNF- $\alpha$ and IFN- $\gamma$ $(10 \mathrm{ng} / \mathrm{ml}$ each) for $24 \mathrm{~h}$. The cell were fixed with paraformaldehye, and were analyzed by cell ELISA, as described in Material and methods. ${ }^{* *} p<0.01$, vs. control; ${ }^{\#} p<0.05,{ }^{\# \#} p<0.01$, vs. TNF$\alpha+$ IFN $-\gamma$ treated alone. Each value shows mean \pm S.E. $(n=3$, individual experiments).

\section{3. 아토피관련 케모카인 발현 분석}

TARC/CCL17과 MDC/CCL22는 대표적인 Th2 케모카인으로 CC chemokine receptor 4(CCR4)을 경유하여 염증부위로 Th2 세포의 이동과 침윤을 유도하는 것 ${ }^{20)}$ 으로 알려져 있다. 또한 아토 피피부염 환자의 혈청에서 다량으로 검출 ${ }^{21)}$ 되어 아토피 피부염 관 련 연구에 중요한 표적 분자이다. $\mathrm{HaCaT}$ 세포에서 배양추출물의 전처리는 $\mathrm{TNF}-\alpha 10 \mathrm{ng} / \mathrm{ml}$ 과 $\mathrm{IFN}-\gamma 10 \mathrm{ng} / \mathrm{ml}$ 에 의한 TARC와 $\mathrm{MDC}$ 의 발현 증가를 농도 의존적으로 감소시켰다(Fig. 3).

아토피피부염에서 RANTES(regulated on activation in normal T-cell expressed and secreted)는 eosinophil과 T 세포의 이동과 활성에 관여하는데 lymphocyte가 내피세포 표면에 부착되는 것을
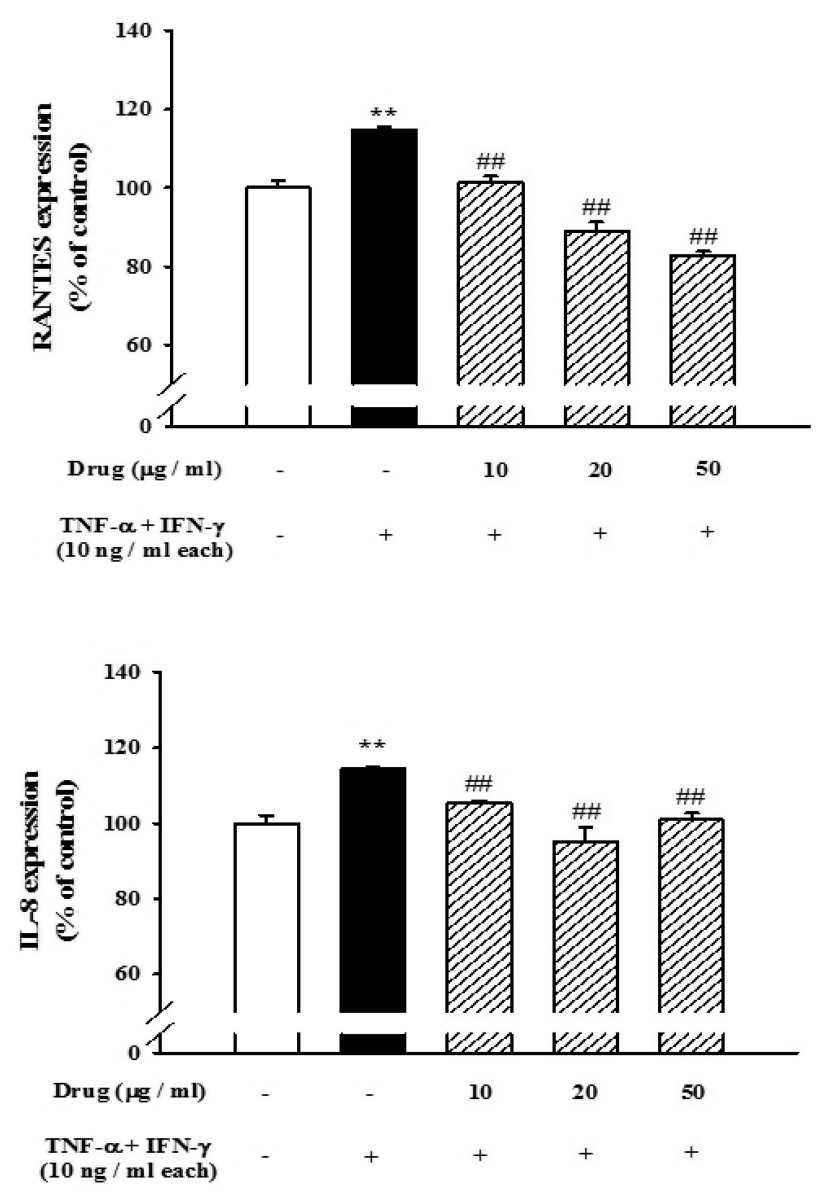

Fig. 4. Effects of Lactobacillus mixture culture fluid extracts on the RANTES and IF-8 expression.

$\mathrm{HaCaT}$ cells were pretreated with Lactobacillus mixture culture fluid extracts for $1 \mathrm{~h}$ and then stimulated with TNF- $\alpha$ and IFN $-\gamma$ $(10 \mathrm{ng} / \mathrm{ml}$ each) for $24 \mathrm{~h}$. The cell were fixed with paraformaldehye, and were analyzed by cell ELISA, as described in Material and methods. ${ }^{* *} p<0.01$, vs. control; ${ }^{\#} p<0.05,{ }^{\# \#} p<0.01$, vs. TNF- $\alpha+$ IFN $-\gamma$ treated alone. Each value shows mean \pm S.E. $(n=3$, individual experiments). 
유도하여 염증을 유발시키는데 관여 ${ }^{22)}$ 한다.

$\mathrm{HaCaT}$ 세포에서 배양추출물에 의한 항염증 및 항알러지 효과를 알아보기 위하여 cell ELISA를 수행하였다. TNF- $\alpha 10 \mathrm{ng} / \mathrm{m}$ 과 IFN- $\gamma 10 \mathrm{ng} / \mathrm{ml}$ 에 의한 RANTES와 IL-8의 발현 증가를 배양추 출물의 전처리에 의하여 농도 의존적으로 감소시켰다(Fig. 4). 그러 므로 배양추출물은 Th2 케모카인의 발현을 농도의존적으로 억제 시켜 아토피피부염 개선에 효과적인 물질이라 사료된다.

이상의 실험결과는 배양추출물이 세포내 신호전달체계를 통한 아 토피관련 유전자를 조절하여 항염증 및 항알러지 효과가 있다고 생 각할 수 있다. 그러나 세포에서의 연구결과는 임상사례와의 보고 ${ }^{19}$ 와는 다른 단순한 양상을 보이고 있었다. 보고된 임상시례 ${ }^{19}$ 에서는 한의학에서 흔히 명현반응이라고 이해될 수 있는 약물의 자극 정도 에 따라 증상이 더욱 심해져 가는 반응이 나타난다. 이 반응은 혼합 배양액을 1회 피부도포한 경우에서도 매 번 나타나고 또한 수 회에 서 수십 회의 피부도포한 경우에서도 나타나는데 1회 피부도포한 경우에서 나타나는 증상의 변화를 반응기(reaction period), 감소 기(reduction period), 효과기(effection period), 재현기(reproduction period), 다 회 피부도포한 경우에서 나타나는 증상이 심 해져 가는 변화를 리바운드기(RBP, rebound period)라 보고하였 다. 세포에서의 연구결과는 임상사례에서 보고된 혼합배양액 도포 횟수가 반복됨에 따라 발생하는 아토피피부염의 증상, 상처범위, 삼출의 정도 등 아토피피부염 증상이 커져가는 양상의 발현을 설명 할 수는 없었다. 이는 실지 임상에서 나타나는 시례의 결과가 매우 복잡하다는 것을 의미하며 이에 대한 연구가 진행되기를 희망한다.

\section{결 론}

최근에 보고된 아토피피부염에 대한 lactobacillus 혼합배양액 피부도포 임상사례를 근거로 $\mathrm{HaCaT}$ 세포를 이용하여 TNF- $\alpha$ 와 interferon- $\gamma$ (IFN- $\gamma$ )로 알러지 반응을 유도한 후, 배양추출물 시 료를 처리한 결과, 염증성 케모카인으로 알려진 TARC/CCL17, $\mathrm{MDC} / \mathrm{CCL} 22$ 및 RANTES/CCL5의 발현량이 농도의존적으로 감소 됨을 확인하였으며, 또한 TNF- $\alpha$ 과 IFN- $\gamma$ 로 유도된 세포내 활성 산소 $(\mathrm{ROS})$ 가 농도의존적으로 감소됨을 확인하였다.

이에 아토피피부염에 효과가 있다고 보고된 lactobacillus 혼합 배양액은 세포내 높은 활성산소 억제능과 항염증 및 항알러지 효과 를 다양한 염증성 케모카인(chemokine)의 억제를 통하여 세포내 직접적인 신호전달 작용으로 아토피피부염 증상 완화에 기여할 수 있다고 사료되나 아직 혼합배양액 도포 시 나타난다고 임상사례에
서 보고된 반응기, 감소기, 효과기, 재현기, 리바운드기 등의 발현에 대해서는 설명할 수 없었고 이에 대한 깊은 연구가 진행되기를 희 망한다.

\section{감사의 글}

This work(Grants No. c0395584) were supported by Business for Cooperative R\&D between Industry, Academy and Research Institute funded Korea Small and Medium Business Administration in 2016.

\section{References}

1. Howlett S. Emotional dysfunction, child-family relationships and childhood atopic dermatitis. Br J Dermatol 1999 ; 140 : 381-4.

2. Foolad N, Brezinski EA, Chase EP. Armstrong AW(2012) Effect of nutrient supplementation on atopic dermatitis in children. Arch Dermatol. $2012 ; 17: 1-6$.

3. Hwang EK. The Clinical Significance of Fungal Allergy in Patients with Atopic Dermatitis. Ajou:Department of Medical Sciences, The Graduate School, Ajou University. Paper of master degree. $2012: 1-34$.

4. David TJ, Wells FE, Sharpe TC, Gibbs AC. Low serum zinc in children with atopic eczema. Br J Dermatol 1984; 111 : 597-601.

5. Searing DA, Leung DY. Vitamin D in atopic dermatitis, asthma and allergic diseases. Immunol Allergy Clin North Am. 2010; 30 : 397-409.

6. Leung DY, Bieber T. Atopic dermatitis. Lancet. 2003 ; 361 : 151-60.

7. Schults-Larsen F, Hanifin JM. Epidermiology of atopic dermatitis. Immunol Allergy Clin. North Am. 2002 ; 22 : 1-24.

8. Soma Y, Kashima M, Imaizumi A, Takahama H, Kawakami T, Mizoguchi M. Moisturizing effects of topical nicotinamide on atopic dry skin. Int J Dermatol. 2005 ; 44 : 197-202.

9. Park TM. Effect of The Herbal Medicine Treatment for Gastrointestinal Dysfuction in Children with Atopic Dermatitis. Pocheon:Major in Comlementary Alternative Medicine Graduate 


\section{KOREAN JOURNAL OF ACUPUNCTURE}

School of Complementary Alternative Medicine. paper of master degree. $2008: 1-43$.

10. Pessi T, Sutas Y, Hurme M, Iolauri E. Interleukin-10 generation in atopic children following oral Lactobacillus rhamnosus GG. Clin. Exp. Allergy $2000 ; 30: 1804-8$.

11. Choi MO, Kim BJ, Jo SK, Jung HK, Lee JT, Kim HY, et al. Anti-allergic activities of Castanea crenata inner shell extracts fermented by Lactobacillus bifermentans. Korean J Food Preserv $2013 ; 20(4): 583-91$.

12. Park HS, Lee HS, Uhm TB. Selection of microorganisms for probiotics and their characterization. J. Korean Soc. Food Sci. Nutr. $1998 ; 27: 433-40$.

13. Klliomaki M, Ouwehand A, Arvilommi H, Kero P, Isolauri E. Transforming growth factor beta in the breastmilk: A potential regulator of atopic disease at an early age. J. Allergy Clin. Immun. 1999; $104: 1251-7$.

14. Lee IH, Lee SH, Lee IS, Park YK, Chung DK, Cho RW. Effects of Probiotic Extracts of Kimchi on Immune Function in NC/Nga Mice. KOREAN J. FOOD. 2008 ; 40(1) : 82-7.

15. Isolauri E, Rautava S, Kalliomaki M, Kirjavainen P, Salminen S. Role of probiotics in food hypersensitivity. Curr Opin Allergy Clin Immunol $2002 ; 2: 263-71$.

16. Brouwer ML, Wolt-Plompen SAA, Dubois AEJ, Van Der Heide S,
Jansen DF, Hoijer MA, et al. No effects of probiotics on atopic dermatitis in infancy: a randomized placebo-controlled trial. Clin Exp Allergy $2006 ; 36:$ 899-906.

17. Grüber C, Wendt M, Sulser C, Lau S, Kulig M, Wahn U, et al. Randomized, placebo-controlled trial of Lactobacillus rhamnosus $\mathrm{GG}$ as treatment of atopic dermatitis in infancy. Allergy $2007 ; 62: 1270-6$.

18. Weston S, Halbert A, Richmond P, Prescott SL. Effects of probiotics on atopic dermatitis: a randomised controlled trial. Arch Dis Child 2005 ; 90 : 892-7.

19. Jo EH, Kim TK, Hong SJ, Jung DY, Hwang SY, Ahn SH. The Case Study of Lactobacillus mixture culture fluid on Atopic dermatitis. J Koean Med. 2015 ; 36(3) : 135-43.

20. Campbell JJ, Haraldsen G, Pan J, Rottman J, Qin S, Ponath P, et al. The chemokine receptor CCR 4 in vascular recognition by cutaneous but not intestinal memory T cells. Nature 1999; $400: 776-80$.

21. Song TW, Kwon BC, Choi SY, Shin YH, Lee KE, Yang HS et al. Increased Serum Thymus and Activation-regulated Chimokine (TARC) Levels in Children with Atopic Dermatitis. Allergy Asthma \& Respiratory Disease. 2005 ; 15(3) : 250-6.

22. Andrew $D$ Luster. The role of chemokines in linking innate and adaptive immunity. Curr Opin Immunol. 2002 ; 14(1) : 129-35. 